\title{
WERKSWAARDES VAN AKADEMICI
}

\author{
LOUDINE CLAASSEN \\ JOHANN M SCHEPERS \\ GERT ROODT \\ Departement Menslikehulpbronbestuur \\ Randse Afrikaanse Universiteit
}

\begin{abstract}
Work values of academics. The purpose of this study was to investigate the workvalues of the academic staff at a South African tertiary institution. The actual in contrast to the idealised workvalues was tested in order to determine the differences between these two sets. Value differences in respect of demographical variables were investigated. The relative strength of each workvalue was also determined. The workvalues were tested utilising three scales developed by Schepers and Roodt (2000). A sample of convenience drawn from a population of academics $(\mathrm{N}=350)$ yielded 125 complete records. The test results indicated that there are differences between the actual and idealised workvalues. Some statistically significant value differences in terms of demographic variables were found. The results also indicated that the workvalue profiles of the different faculties are very similar.
\end{abstract}

\section{OPSOMMING}

Die doel van die studie was om die werkswaardes van akademici aan 'n Suid-Afrikaanse tersiêre instelling te ondersoek. Die werklike teenoor die geïdealiseerde werkswaardes is gemeet ten einde vas te stel of die twee waardestelle verskil. Waardeverskille ten opsigte van verskeie demografiese veranderlikes is ondersoek. Die relatiewe sterkte van elke werkswaardes is ook bepaal. Drie meetinstrumente, ontwikkel deur Schepers en Roodt (2000), is hiervoor gebruik. ' $n$ Geleentheidsteekproef, getrek uit die populasie van akademici $(\mathrm{N}=350)$, het 125 volledige rekords opgelewer. Die resultate dui daarop dat daar statisties-beduidende verskille bestaan tussen die ideale en werklike werkswaardes. Enkele statisties-beduidende waardeverskille in terme van demografiese veranderlikes is gevind. Laastens dui die resultate daarop dat die werkswaardeprofiele van die verskillende fakulteite baie eenders is.

\section{SYNOPSIS}

Values are defined in various ways, but a common theme emerging from the literature is that values are conceptions, ideas or beliefs about some desired end state. An overview of the literature on values identified several value domains. The first domain focuses on general life values, the second on community and social values and the third domain on work values. General life values play an important role in decision-making; they act as a moral and ethical standard; and also have a motivational role. Several measures have been developed to measure general life values.

Diverse community and social values pose a management challenge in the diverse South African context. People are socialised in different cultures and communities, which result in diverse and often unique value sets. These people from diverse backgrounds end up working for the same organisation. The challenge for managers amongst others is to develop a common value system for all employees. These values should act as guiding principles for people in the work context. Several measures have been developed for assessing work values, but were not used in the present study.

The goal of the study conducted at a tertiary institution was threefold: The first objective was to determine whether there were differences in terms of current and idealised work values; the second objective was to determine if there were work value differences in respect of demographic variables; the third objective was to determine the degree of similarity of the work value profiles of different faculties.

Three scales and a biographical inventory were completed by a sample of convenience of 125 respondents. The sample was drawn from a population of 350 academics which yielded a response rate of about 36\%. The scales designed by Schepers and Roodt (2000) measured the importance of ten work values, namely completion orientation, client needs orientation, professionality, integrity, innovation, excellence, transparency, loyalty, consistency and competence. Scale A measures the importance of work values by using paired comparisons; Scales $B$ and $C$ are normative scales and measures the idealised work values and the current work values of

Requests for copies should be addressed to: L Claassen, Departement

Menslikehulpbronbestuur, RAU, Posbus 524, Aucklandpark, 2006 respondents. Responses to Scales $B$ and $C$ are measured on a sevenpoint intensity scale anchored at the end-points. The biographical inventory scales the demographic information of respondents, such as age, home language and faculty.

The questionnaires were distributed together with a covering letter in sealed envelopes. Heads of departments were requested to distribute the questionnaires to staff members. Completed questionnaires were collected in sealed envelopes by the heads of departments. Respondents could participate in a voluntary and anonymous way.

Principal factor analyses of Scales $B$ and $C$ separately yielded three factors each, and jointly four factors. The obtaioned factors were identified.

Statistically significant differences between the idealised and current values were obtained for the following work values: professionalism, integrity, innovation, excellence, transparency, consistency and competence. It seems that respondents want to see these idealised values more strongly endorsed for the transforming higher education context.

Significant differences were found between the current work values of differenct age groups: In respect of completion orientation, innovation, excellence, transparency and consistency the group older than 49 years obtained higher scores than the group younger than 36 years. It appears that older academics have better crystalised work value systems. With regard to idealised work values an overall difference was found between faculties with regard to consistency. As far as ranks are concerned a difference was found in respect of integrity.

A comparison of the work value profiles of faculties yielded high coefficients of profile similarity. The different faculties seem to share a similar value system which can be attributed to selection procedures and/or socialisation processes in the institution.

Hoër-onderwys in Suid-Afrika word gekenmerk deur transformasie waavan die impak nie slegs studente raak nie, maar ook die tersiêre instellings self en die doserende personeel wat daar werksaam is. Die werkwaardes van akademici sa 
toenemend belangriker word as rigtinggewende meganisme in 'n turbulente en kultureel-diverse omgewing. 'n Stel gedeelde werkwaardes kan in hierdie opsig van groot waarde wees om etiese en professionele gedrag en hoë standaarde van vakkundige dienslewering te bevorder.

Waardes in die Suid-Afrikaanse hoër-onderwyskonteks

Die keuse van waardes is bepalend vir ten minste drie belangrike oorwegings in 'n opleidingskonteks:

- om die intellektuele vaardighede, vermoëns en kritiese talente van die studente te ontwikkel.

- om die ryk verskeidenheid en diversiteit van ons land se kultuur en taal in te sluit.

- om studente toe te rus met vaardighede om die uitdagings van die lewe te kan aanpak en nie as ' $n$ bedreiging te sien nie (James, 2000).

'n Suksesvolle nasie word gekenmerk deur opgeleide burgers. 'n Opleidingsisteem wat aan bogenoemde drie oorwegings voldoen, laat die talent van die jeug toe om in 'n diverse omgewing te ontluik. Dit is belangrik dat hierdie waardes aan hedendaagse studente oorgedra word tydens leer. Dit is dus belangrik dat opleiers eienaarskap aanvaar van die waardes sodat hulle dit doeltreffend kan oordra. Uit die bogenoemde blyk dit duidelik dat die opleidingsinstellings ook hierdie waardes sal moet reflekteer (James, 2000).

Soos reeds uitgewys, word tersiêre instellings deur transformasie geraak. Nuwe konsepte soos uitkomsgebaseerde onderwys en erkenning van vorige leer is besig om deel te word van die instellings se leerstelsels. Gegewe hierdie veranderinge kom die vraag na vore watter werkswaardes vir die opleiers en akademici belangrik is in hierdie veranderende werksomgewing. Verder word gevra of akademici die werkswaardes, wat die veranderende opleidingsomgewing rugsteun, belangrik ag.

Ten einde duidelikheid te verkry oor die begrip werkswaardes, sal daar eerstens na algemene lewenswaardes en vervolgens na gemeenskaps- en sosiale waardes verwys word.

\section{Algemene lewenswaardes}

In die literatuur word daar verskeie beskouings oor die begrip 'lewenswaardes' weergegee. Desnieteenstaande word 'n aantal kenmerke van lewenswaardes deur die literatuurskrywers gedeel. Hofstede (1998) en, Schwartz en Bilsky (1987) steun die standpunt soos onderskryf deur Allport (1961), Levy en Guttman (1974), Maslow (1959), Morris (1956), Pepper (1958), Rokeach (1973), Scott (1965), Smith (1963), en Williams (1968) waarin lewenswaardes omskryf word as 'n begrip, idee of oortuiging van 'n begeerlike eindtoestand van gedrag. Die wyse waarop die eindresultaat bereik word, is om 'n spesifieke situasie bo ' $n$ ander te kies. Die keuse lei tot 'n evaluasie van gedrag of gebeurtenisse en word in prioriteitsorde geplaas. Swart, Roodt en Schepers (1999) ondersteun bogenoemde siening in hul studie. Volgens die definisie van Smith en Hattingh (1995, p.3) speel waardes ' $n$ rol in situasies waarin die mens voorkeur gee aan dít wat belangrik en wenslik geag word.

Die mens se lewenswaardes word volgens Lusk en Olivier (1974, p.549) as 'n relatief permanente oortuigingsraamwerk beskou wat die aard van sy/haar gedrag vorm en beïnvloed. Waardes gee duidelikheid aan menslike gedrag omdat dit as standaarde van optrede dien (Kamakura \& Mazzon, 1991, p.208). Volgens Katzell (1964) ontwikkel en verander lewenswaardes deur die persoon se lewenservaringe. Waardes is dit wat vir die mens belangrik is in sy lewe en word ook weerspieël in die onderskeid tussen reg en verkeerd (Mindell \& Gorden, 1981, p.14).

Lewenswaardes vervul bepaalde funksies: Dit dien as standaard, besluitnemingsriglyn, en motiveerder. Lewenswaardes word gesien as multi-dimensionele standaarde wat gedrag rig (Rokeach 1973, p.13). Die wyse waarop die mens homself ag en teenoor ander projekteer, word ook bepaal deur sy/haar waardestelsel. Waardes is die bepaler of standaard van die wyse waardeur die mens ander beinvloed en oorreed om sekere oortuigings, houdings en optredes aan te hang. Waardes speel dus ' $n$ belangrike rol in die sosiale posisie waar die mens hom/haarself sien en wat hom/haar van ander onderskei (Roodt, 1991).

Die besluitnemingsrol van waardes is kernbelangrik in die mens se bestaan. Wanneer ' $n$ keuse vereis word in 'n onduidelike situasie, sal die besluit op grond van die persoon se waardestelsel geneem word. Aangeleerde reëls en beginsels rig die mens se besluitneming in intra-individuele konfliksituasies. Waardestelsels verhinder soms 'n mens om regte besluite te neem en regte doelwitte te bereik, indien die verkeerde waardekeuses gemaak word (Roodt, 1991).

Rokeach (1973) onderskei in sy navorsing tussen twee tipes lewenswaardes: terminale waardes wat na eindtoestande van die menslike bestaan verwys en instrumentele waardes wat gedrag rig ten einde hierdie eindtoestande te bereik (Roodt, 1991, Verwey \& Fouche, 1987). Terminale waardes is motiverend omdat hierdie tipe waardes gerig is op belangrike doelwitte eerder as om biologiese behoeftes te bevredig. Instrumentele waardes hierteenoor is motiverend vanweë hul funksie om die mens se gedrag te lei ten einde die beoogde einddoelwitte te bereik. Hieruit blyk dat waardes ook 'n motiveringsfunksie het (Rokeach, 1973).

Samevattend kan die begrip lewenswaardes aan die hand van 'n opsomming van die funksies daarvan verklaar word. Smith (in Pietrofesa, Bernstein, Minor \& Stanford, 1980) vat die genoemde funksies van waardes in die volgende opsomming saam:

a) waardes gee rigting en betekenis aan die mens se bestaan;

b) waardes vorm die basis vir individuele en kollektiewe optrede;

c) waardes dien as basis om gedrag van ander te evalueer;

d) waardes stel die mens in staat om te weet wat van hom verwag word en hoe om homself/haarself te handhaaf, en

e) waardes verleen aan die mens die vermoë om te onderskei tussen reg en verkeerd.

Daar is reeds talle studies oor lewenswaardes gedoen. Van die bekendste studies sal vervolgens bespreek word. Hierdie studies het ook as basis gedien vir die ontwikkeling en verfyning van die konsep 'werkswaardes' wat in die onderhawige studie gebruik is.

Allport, Vernon en Lindzey (1960) se navorsing oor lewenswaardes is van die bekendste navorsing in hierdie veld. Die navorsing is gedoen met hul "Study of Values" instrument. Die instrument is ontwerp om die aanwesigheid van ses basiese waardes in die mens se persoonlikheid te meet. Kritiek volgens Hoelsen en Stead (1998) is dat hierdie instrument 'n ipsatiewe meting is en hoofsaaklik geskoei is op waardes wat verwant is aan belangstellings, eerder as waardes wat verband hou met sosiale transformasie.

Rokeach (1973) se instrument die Rokeach Value Survey is gebruik om algemene lewenswaardes te meet. Die skaal meet 18 terminale waardes en 18 instrumentele waardes. Kritiek wat uitgespreek word teen die Rokeach Value Survey is dat daar nie aangedui word hoe daar te werk gegaan is om die waardes te selekteer nie (Braithwaite \& Law, 1985; Feather, 1973; Gorsuch, 1970; Kamakura \& Novak, 1992). Die Rokeach instrument is volgens Kamakura en Novak (1992) verfyn deur Kahle (1983), wat die List of Values tot gevolg gehad het. Hierdie instrument toets slegs nege van die genoemde 18 terminale waardes. Die instrument kombineer of veralgemeen die waardes wat gebruik is in die Rokeach Value Survey om sodoende slegs met nege waardes vorendag te kom.

Joubert (1988) het verskeie waardeklassifikasies en hul onderliggende beginsels bestudeer en gepoog om 
waarde-oriëntasie van ander waardekonstrukte te onderskei. Daar is tot die gevolgtrekking gekom dat die bestaande klassifikasies uitsluitlik betrekking het op houdings en belangstellings. In meer kontemporêre navorsing word die studie van waardes egter as deel van die sosiale werklikheid beskou. Volgens hierdie beskouing word waardes voortdurend opgebou en verander deur die dinamiese interverwantskappe van gedrag, oortuigings en omstandighede (Hoelsen \& Stead, 1998).

Bogemelde funksies van lewenswaardes kan ook deurgetrek word na die funksies wat gemeenskapswaardes en uiteindelik ook werkswaardes vervul. Sosiale waardes en werkswaardes sal aan die hand van die mees resente literatuur bespreek word.

\section{Gemeenskaps- en sosiale waardes}

Bode (1997) bevestig die standpunte van Hattingh (1991) dat individue nie met waardes gebore word nie, maar wel met 'n waarde-bewussyn. Waardes word ontwikkel aan die hand van die gemeenskapskultuur, die rol van ouers, instellings en lewensondervinding. Waardes word oorgedra deur sosiale sisteme en kulture en die individu verkry eienaarskap van sy eie unieke waardesisteem deur deelname aan die proses van waardeseleksie. In 'n dinamiese sisteem wat gekenmerk word deur komplekse netwerke tussen die komponente van die sisteem, is dit vanselfsprekend dat ' $n$ verandering in een deel van die sisteem die hele sisteem se interaktiewe prosesse sal beïnvloed.

In die vinnig-veranderende Suid-Afrikaanse omgewing, kan dit verwag word dat politieke, ekonomiese, kulturele en ander sosiale veranderinge die lewens van individue sal beïvloed. Dit gebeur deur die wisselwerking tussen die individu en sy omgewing wat 'n invloed het op sy waardes (Hoelsen \& Stead, 1998). Die Suid-Afrikaanse gemeenskap word gekenmerk deur kultureel-diverse groepe. Hierdie groepe ontmoet in werksverband en koöpteer hul eie subkulture en waardes in die werksplek. Die organisasie-omgewing waarin individue hul bevind, is 'n derde bron van invloed met sy eie unieke subkultuur en waardes (Emmet, 1988; Flowers, 1988). Oosthuizen (1996) ondersteun bogenoemde siening. Die individu en die organisasie waarin gefunksioneer word, bestaan in 'n gemeenskap met 'n eie unieke gemeenskapskultuur en waardestelsel. Gevolglik beïnvloed die gemeenskap asook die organisasie die mens se waardestelsel (Verwey \& Fouche, 1987). Vanweë die genoemde kenmerke van die SuidAfrikaanse gemeenskap, blyk dit dat dit ongekende moeite van die organisasie verg om sy werknemers te sosialiseer (Emmet, 1988). Sosialisering is in wese die integrasie van verskillende waardestelsels in die werksmilieu.

\section{Werkswaardes}

Volgens Oosthuizen (1996) word daar vandag ongekende veranderinge beleef in die breë samelewingsverband, asook in organisasies. Hierdie veranderinge neem deurgaans in tempo, omvang en intensiteit toe. Die veranderinge het 'n invloed op die werksomgewing, wat gekenmerk word deur kompleksiteit, onstabiliteit en onsekerheid. Dit is egter die omgewing waar die individu sy lewenswaardes uitleef in terme van sy werksrol.

Swart et al. (1999) beskou werkswaardes as 'n subdomein van algemene lewenswaardes. Smith en Hattingh (1995, p.3) definieer werkswaardes as dít wat die individu as belangrik of wenslik ervaar binne sy/haar werksituasie. Werkswaardes het dus betrekking op die individu se werk en dit wat hy ervaar en waardeur hy gemotiveer word. Dit lei tot werkstevredenheid of ontevredenheid. Flowers (1988, p.5) definieer werkswaardes as waardes wat intrinsiek asook ekstrinsiek tot werkstevredenheid lei indien dit bevredig word en omvat die uitkomste wat 'n individu in sy werk verlang. Werkswaardes verwys na 'n norm waarteen uitkomstes en optredes in werksverband beoordeel kan word. Werkswaardes vorm onder meer ook die dryfkrag wat die individu motiveer om te werk. Die mens moet in die huidige wêreld van werk meer aanpasbaar wees as in die verlede en sal dus oor die waardes en vermoëns moet beskik om in 'n voortdurendveranderende werksomgewing te funksioneer. Juis vanweë die verskille en veranderinge in die land, kan dit verwag word dat daar verskille sal wees in werkswaardes van individue binne dieselfde werksomgewing.

Vorige navorsing wat spesifiek toegespits was op die meting van werkswaardes in die algemeen, sal ook ter stawing van die studie van werkswaardes in hierdie artikel aangehaal word.

Die meetinstrument Work Value Inventory is deur Super ontwikkel en meet werkswaardes. Dit is ontwikkel ten einde die beroepswaardes van studente en volwassenes te meet. Die groepering van werkswaardes dui op ekstrinsieke, intrinsieke en vaardigheidswaardes. Dit word gekoppel aan Maslow (1959) se behoefte-hiërargie waar verwys word na die verband tussen werkswaardes en behoeftes (Emmet, 1988).

In 'n vergelykende studie van werkswaardes deur Hofstede (1980) is 'n groot aantal nasionale kulture getoets. Daar is vier kulturele dimensies geïdentifiseer (Hofstede \& Bond, 1984; Hofstede, 1998). Ofskoon die betrokke studie ook op werkswaardes gefokus het, moet die resultate van hul studie met versigtigheid geinterpreteer word ( $c f$. Kruger \& Roodt, 2003), aangesien die toetsing slegs binne 'n enkele maatskappy gedoen is en die resultate na die wyer gemeenskap veralgemeen is.

Smith en Hattingh (1995) het 'n werkswaardevraelys ontwikkel vir toepassing op 'n finansiële instelling. Volgens Swart et al. (1999) beskik dié meetinstrument oor goeie konstrukgeldigheid. Ten spyte hiervan kon dit nie vir die doeleindes van hierdie artikel gebruik word nie vanweë die feit dat dit organisasie- en industriespesifiek is.

Volgens Bode (1997) het Engelbrecht (1991) 'n werkswaardeskaal ontwikkel ten einde werkswaardes spesifiek in Suid-Afrika te meet. Hierdie vraelys meet vier faktore en is gebaseer op Hofstede se dimensies. Die instrument is onder meer ook deur Hugo en van Vuuren (1996) in hul studie gebruik. Alhoewel die instrument ook van toepassing is op die Suid-Afrikaanse kultuur was dit nie vir die doeleindes van hierdie artikel geskik nie, aangesien die doelwit van die onderhawige navorsing nie fokus op die breë Suid-Afrikaanse universum nie, maar slegs op akademici.

Gegewe die teenswoordige konteks in Hoër-onderwys, mag dit nuttig wees om te bepaal watter werkswaardes deur akademici belangrik geag word

Die doel van die studie

Die doelstellings van hierdie artikel is drieledig:

Eerstens om te bepaal of daar wel 'n verskil bestaan tussen die geïdealiseerde en werklike werkswaardes van akademici;

Tweedens om te bepaal of daar verskille is in die werkswaardes van verskillende demografiese groepe, en

Derdens om die relatiewe sterktes van die werkswaardes van akademici gestratifiseerd te ondersoek ten einde die graad van profieleendersheid van die verskillende fakulteite te bepaal.

Die studie van Hugo en van Vuuren (1996) dui daarop dat die werksomgewing ' $n$ sfeer is waar lewens- en sosiale waardes uitgeleef word. Super (1984) beklemtoon ook dat daar bepaalde verskille in werkswaardes bestaan tussen verskillende groepe in dieselfde land. Daar is volgens Elizur (1996) en Bode (1997) 'n groeiende belangstelling in 
die ontleding van menslike waardes, veral in die werkskonteks, vanweë die feit dat daar 'n groot diskrepansie bestaan tussen die geïdealiseerde werkswaardes en die gemanifesteerde werkswaardes van werkers. Daar kan dus verwag word dat daar wel 'n verskil in werkswaardes onder die proefpersone mag voorkom. Dit is belangrik dat die transformasie wat plaasvind in die Hoër-Onderwysstelsel, deur waardes gelei word, anders mag die universiteite en akademici skade ly (Rossouw, 1996).

Ten einde uitvoering aan die navorsingsdoelwitte te gee, is die ondersoek aan 'n tersiêre instelling gedoen aan die hand van die volgende toetsbare hipoteses:

Hipotese 1:

Daar bestaan statisties-beduidende verskille in gemiddeldes tussen die werklike en gëidealiseerde werkwaardes van akademici.

Hipotese 2:

Daar bestaan statisties-beduidende verskille in die gemiddeldes van groepe gevorm aan die hand van demografiese veranderlikes soos fakulteite, range, geslag, taal en ouderdom.

Hipotese 3:

Die werkswaardeprofiele van die verskillende fakulteite verskil statisties-beduidend van mekaar.

\section{NAVORSINGSONTWERP}

Die navorsingsbenadering en -metodologie wat in hierdie studie gevolg is, sal in meer besonderhede hieronder bespreek word:

\section{Navorsingsbenadering}

Die studie kan as ' $n$ tipiese kwantitatiewe ondersoek en as ' $n$ dwarssnit, veldopname geklassifiseer word. Die primêre data wat deur die veldopname gegenereer is, is deur korrelasionele tegnieke ontleed wat die ontleding as ' $\mathrm{n}$ ex post facto benadering sal tipeer.

\section{Navorsingsmetodologie}

Die navorsingsmetodologie van die studie word hieronder aan die hand van drie hoofde aangebied:

\section{Steekproef}

Vir die doel van hierdie studie was die navorsing toegespits op die akademiese populasie van 'n tersiêre instelling. Die steekproef is saamgestel uit alle fakulteite, werksrange, geslagte, ouderdomsgroepe en taalgebruikers aan die instelling. Uit die totale populasie van 350 het 125 gerespondeer. Dit gee 'n responskoers van bykans $36 \%$. Die demografiese gegewens van die steekproef verskyn in Tabel 1.

Uit Tabel 1 blyk dit dat die grootste persentasie van die respondente werksaam was in die Fakulteite Ingenieurswese en Natuurwetenskappe (30\%). Wat range betref was die grootste persentasie respondente professore $(34 \%)$. Die grootste persentasie van die steekproef was manlik (54\%), en Afrikaanssprekend (85\%). Die ouderdomme van die respondente het gevarieer tussen 23 jaar en 64 jaar en die grootste persentasie van die respondente was tussen 37 jaar en 49 jaar (34\%).

Twee respondente het op 'n uiters ekstreme wyse gerespondeer ten opsigte van Afdeling A, sodanig dat die waardes van hul protokolle betwyfel is en gevolglik verwyder is van die steekproef vir ontledingsdoeleindes.

\section{Meetinstrumente}

Ofskoon daar reeds verskeie waardevraelyste bestaan wat spesifiek gefokus is op die meting van werkwaardes in die SuidAfrikaanse konteks, was daar nie 'n geskikte instrument beskikbaar vir die doeleindes van hierdie studie nie.
TABel 1

RESPONDENTE SE DEMOGRAFIESE AGTERGROND

\begin{tabular}{|c|c|c|}
\hline Biografiese veranderlikes & $\begin{array}{c}\text { Frekwensie } \\
\mathrm{N}\end{array}$ & $\begin{array}{c}\text { Persentasie } \\
\%\end{array}$ \\
\hline \multicolumn{3}{|l|}{ FAKULEITE } \\
\hline Ekonomies \& Bestuurswetenskappe & 30 & $24 \%$ \\
\hline Ingenieurswese/Natuurwetenskappe & 37 & $30 \%$ \\
\hline Lettere \& Wysbegeerte & 33 & $26 \%$ \\
\hline Opvoedkunde \& Verpleegkunde & 14 & $11 \%$ \\
\hline Ander & $\underline{11}$ & $\underline{9 \%}$ \\
\hline Totaal & 125 & $100 \%$ \\
\hline \multicolumn{3}{|l|}{ RANGE } \\
\hline Junior Lektor & 10 & $8 \%$ \\
\hline Lektor & 23 & $18 \%$ \\
\hline Senior Lektor & 25 & $20 \%$ \\
\hline Medeprofessor & 21 & $17 \%$ \\
\hline Professor & 43 & $34 \%$ \\
\hline Onbekend & $\underline{3}$ & $\underline{2 \%}$ \\
\hline Totaal & 125 & $100 \%$ \\
\hline \multicolumn{3}{|l|}{ GESLAG } \\
\hline Manlik & 68 & $54 \%$ \\
\hline Vroulik & 52 & $42 \%$ \\
\hline Onbekend & $\underline{5}$ & $\underline{4 \%}$ \\
\hline Totaal & 125 & $100 \%$ \\
\hline \multicolumn{3}{|l|}{ HUISTAAL } \\
\hline Afrikaans & 106 & $85 \%$ \\
\hline Engels & $\underline{19}$ & $\underline{15 \%}$ \\
\hline Totaal & 125 & $100 \%$ \\
\hline \multicolumn{3}{|l|}{ OUDERDOM } \\
\hline 36 en jonger & 37 & $30 \%$ \\
\hline 37 tot 49 & 42 & $34 \%$ \\
\hline 49 en ouer & 33 & $26 \%$ \\
\hline Onbekend & $\underline{13}$ & $\underline{10 \%}$ \\
\hline Totaal & 125 & $100 \%$ \\
\hline
\end{tabular}

Ten einde die doelstelling van hierdie studie te verwesenlik, is besluit om drie instrumente, ontwikkel deur Schepers en Roodt (2000), te gebruik. Al drie hierdie meetinstrumente is gekontekstualiseer vir 'n akademiese omgewing met spesifieke akademiesgerigte werkswaardes.

In die ontleding van Skaal A is van Torgerson (1958) se Konstante-Som-Metode (een van die fraksioneringstegnieke) gebruik gemaak. Tien werkswaardes is getoets, synde afhandelingsingesteldheid, kliëntebehoefte-oriëntasie, professionaliteit, integriteit, innovasie, uitnemendheid, deursigtigheid, lojaliteit, konsekwentheid en bevoegdheid. Die werkswaardes is paarsgewys aan die proefpersone gebied. Die doel was dat die proefpersone elkeen van die werkswaardes op grond van die belangrikheid daarvan in sy of haar werk moes beoordeel. Ten opsigte van elke paar werkswaardes wat teenoormekaar gestel is, was daar 'n totaal van 100 punte wat tussen die twee waardes verdeel moes word. Skaal A het ten doel gehad om die relatiewe sterkte van die werkswaardes binne die geledere van akademici te bepaal.

Skale B en C is normatiewe skale. Die doel van Skale B en C was om op normatiewe vlak vas te stel hoe hoog of laag die bepaalde werkswaardes in die mondering van die akademici staan. Skaal B bepaal die werkswaardes, gesien uit 'n idealistiese oogpunt, terwyl Skaal C die werkswaardes bepaal soos wat die respondent dit in die praktyk beleef. Vir albei die skale word die werkswaardes op 'n sewepunt skaal geëndosseer waarvan net die twee eindpole gedefinieer is. 'n 
Waarde van een dui aan dat die werkswaarde van weining of geen belang is in die werksituasie en 'n waarde van sewe dui daarop dat die werkswaarde van die hoogste belang is in die werksituasie.

Aldrie die instrumente is in sowel Engels as Afrikaans beskikbaar gestel ten einde die akademici se taalvoorkeur te akkommodeer.

\section{Prosedure}

'n Omsendbrief om die doel van die toetsing te verduidelik is van die Dekaanskantoor: Ekonomies en Bestuurswetenskappe uitgestuur na elke Departementele Voorsitter. Daarmee saam is 'n koevert met die volgende daarin aan elke akademiese personeellid in die betrokke Departement gestuur:

- 'n Dekblad met duidelike instruksies oor die voltooiing van die vraelyste;

- 'n Demografiese vraelys;

- Afdelings A ,B en C met meegaande antwoordblaaie, en

- 'n Geadresseerde koevert vir die terugstuur van die voltooide vraelyste.

Die vraelyste is anoniem voltooi ten einde vertroulikheid te handhaaf. Al die vraelyste is gedurende dieselfde sessie voltooi, sodoende is die uitvalsyfer geminimeer. Die deelnemers het aldrie die vraelyste byderhand gehad en kon terugverwys indien hulle dit sou verkies. Die voltooide vraelyste is in die voorafgeadresseerde koevert geplaas en aan die navorser besorg.

Die Departementele Voorsitters is deur die navorser telefonies gekontak om vas te stel of die proses glad verloop het en om weereens te benadruk dat dit van belang is dat soveel personeel moontlik aangemoedig moet word om die vraelyste te voltooi. Daarna is elke personeellid afsonderlik deur middel van e-pos gekontak as finale opvolgmaatreël.

\section{RESULTATE}

Soos reeds genoem, was die doelstellings van hierdie studie drieledig: om op normatiewe vlak met behulp van Skale $B$ en $C$ te bepaal hoedanig die geïdealiseerde werkswaardes van akademici van hul werklike werkswaardes verskil; om te bepaal of daar beduidende verskille in die gemiddelde werkwaardes van die verskillende demografiese groepe is; en om die relatiewe sterktes van die werkswaardes van die akademici van elke fakulteit afsonderlik, te bepaal. Die statistiese verwerking van die data is deur die Statistiese Konsultasiediens van die Randse Afrikaanse Universiteit gedoen.

Met die ontleding van Skale B en C, is besluit om die Skale aan ' $\mathrm{n}$ faktorontleding te onderwerp. Die Skale is afsonderlik en gesamentlik aan faktorontleding onderwerp. Die prosedures wat vir Skale B en C gevolg is, stem ooreen, gevolglik sal slegs die prosedure wat met Skaal B gevolg is, in detail beskryf word. Slegs die resultate van die prosedures gevolg met Skaal C en Skale B en $\mathrm{C}$ gesamentlik, sal gegee word.

Skaal B het betrekking op geidealiseerde werkswaardes; voorts sal bloot verwys word na Skaal B. Skaal C het betrekking op werklike werkswaardes; vervolgens sal bloot verwys word na Skaal C.

Die 10 items van Skaal B is geinterkorreleer en die eigenwaardes van die ongereduseerde interkorrelasiematriks is bepaal. Die tabel wat die interkorrelasiematriks aandui, is op aanvraag beskikbaar.

In die bepaling van die getal faktore wat onttrek moet word, is deurgaans van Kaiser (1961) se kriterium (eigenwaardes groter as een) gebruik gemaak. Dit blyk uit die verkreë eigenwaardes van Skaal B, dat drie eigenwaardes groter is as een.
Gevolglik is drie faktore onttrek. Die verkreë faktore is met behulp van die Direct Oblimin-rotasie na eenvoudige struktuur geroteer. Die geroteerde faktormatriks verskyn in Tabel 2, asook die interkorrelasies tussen die faktore.

TABEL 2

GEROTEERDE FAKTORMATRIKS VAN GEÏDEALISEERDE WERKSWAARDES (DIRECT OBLIMIN-ROTASIE)

\begin{tabular}{lcccc}
\hline & FAKTOR 1 & FAKTOR 2 & FAKTOR 3 & $\mathbf{h}^{\mathbf{2}} \mathbf{j}$ \\
\hline Lojaliteit & $\mathbf{0 , 9 0 4}$ & $-0,090$ & $-0,080$ & 0,724 \\
Konsekwentheid & $\mathbf{0 , 5 7 6}$ & 0,234 & 0,049 & 0,505 \\
Afhandelingsingesteldheid & $\mathbf{0 , 5 3 2}$ & $-0,158$ & 0,287 & 0,435 \\
Deursigtigheid & $\mathbf{0 , 4 7 3}$ & 0,265 & 0,029 & 0,390 \\
Uitnemendheid & $-0,142$ & $\mathbf{0 , 7 5 3}$ & 0,117 & 0,582 \\
Innovasie & 0,157 & $\mathbf{0 , 5 8 9}$ & $-0,040$ & 0,410 \\
Professionaliteit & $-0,080$ & $-0,080$ & $\mathbf{0 , 7 6 4}$ & 0,506 \\
Integriteit & 0,062 & 0,231 & $\mathbf{0 , 4 9 0}$ & 0,411 \\
Kliëntebehoefte-oriëntasie & 0,182 & 0,065 & $\mathbf{0 , 3 6 7}$ & 0,252 \\
Bevoegdheid & 0,116 & 0,237 & $\mathbf{0 , 3 4 1}$ & 0,293 \\
\hline
\end{tabular}

INTERKORRELASIES VAN FAKTORE

\begin{tabular}{lccc}
\hline & FAKTOR 1 & FAKTOR 2 & FAKTOR 3 \\
\hline FAKTOR 1 & 1,000 & 0,312 & 0,421 \\
FAKTOR 2 & 0,312 & 1,000 & 0,351 \\
FAKTOR 3 & 0,421 & 0,351 & 1,000 \\
\hline
\end{tabular}

As die geroteerde faktormatriks beskou word, blyk dit dat die volgende werkswaardes hoog laai op Faktor 1: lojaliteit $(0,904)$, konsekwentheid $(0,576)$, afhandelingsingesteldheid $(0,532)$ en deursigtigheid $(0,473)$. Faktor 1 is dus goed bepaal.

Die volgende werkswaardes laai hoog op Faktor 2: uitnemendheid $(0,753)$ en innovasie $(0,589)$. Albei hierdie werkswaardes het beduidende ladings op Faktor 2. Die faktor is egter nie goed bepaal nie.

Die werkswaardes wat hoog laai op Faktor 3 is soos volg: professionaliteit $(0,764)$, integriteit $(0,490)$, kliëntebehoefteoriëntasie $(0,367)$ en bevoegdheid $(0,341)$. Professionaliteit en integriteit het betreklik hoë ladings op Faktor 3, terwyl kliëntebehoefte-oriëntasie en bevoegdheid lae ladings op Faktor 3 het. Faktor 3 is relatief goed bepaal. Faktore 1, 2 en 3 is onderling matig gekorreleer. Hierdie drie faktore verklaar $60,23 \%$ van die totale variansie van Skaal B (geïdealiseerde waardes).

Die betroubaarheid van Skaal B as geheel is 0,776 volgens Cronbach se koëffisiënt alfa.

Die 10 werkswaardes van Skaal C is geïnterkorreleer en die eigenwaardes van die ongereduseerde interkorrelasiematriks is bereken.

Dit blyk uit die eigenwaardes van Skaal C, dat drie eigenwaardes groter is as een. Voorts is drie faktore onttrek en na eenvoudige struktuur geroteer met behulp van die Direct Oblimin-rotasie. Die faktormatriks, asook die interkorrelasies tussen die faktore, verskyn in Tabel 3.

As die geroteerde faktormatriks beskou word, blyk dit dat die volgende werkswaardes hoog laai op Faktor 1: professionaliteit $(0,859)$, integriteit $(0,790)$, uitnemendheid $(0,760)$ en bevoegdheid $(0,678)$. Al vier die werkswaardes het hoë ladings op Faktor 1. Faktor 1 is dus goed bepaal. 
TABEL 3

GEROTEERDE FAKTORMATRIKS VAN WERKLIKE WERKSWAARDES (DIRECT OBLIMIN-ROTASIE)

\begin{tabular}{lcccc}
\hline & FAKTOR 1 & FAKTOR 2 & FAKTOR 3 & $\mathbf{h}^{\mathbf{2}} \mathbf{~}$ \\
\hline Professionaliteit & $\mathbf{0 , 8 5 9}$ & $-0,080$ & 0,113 & 0,778 \\
Integriteit & $\mathbf{0 , 7 9 0}$ & 0,041 & $-0,030$ & 0,640 \\
Uitnemendheid & $\mathbf{0 , 7 6 0}$ & 0,043 & 0,019 & 0,638 \\
Bevoegdheid & $\mathbf{0 , 6 7 8}$ & 0,028 & 0,038 & 0,516 \\
Lojaliteit & $-0,003$ & $\mathbf{0 , 7 5 9}$ & 0,017 & 0,585 \\
Deursigtigheid & $-0,040$ & $\mathbf{0 , 7 4 6}$ & 0,210 & 0,697 \\
Konsekwentheid & 0,302 & 0,624 & $-\mathbf{0 , 1 3 3}$ & 0,607 \\
Kliëntebehoefte-oriëntasie & 0,062 & $-0,080$ & $\mathbf{0 , 7 8 6}$ & 0,619 \\
Innovasie & 0,168 & 0,093 & $\mathbf{0 , 5 5 5}$ & 0,519 \\
Afhandelingsingesteldheid & 0,003 & 0,168 & $\mathbf{0 , 3 3 7}$ & 0,194 \\
\hline
\end{tabular}

\section{INTERKORRELASIES VAN FAKTORE}

\begin{tabular}{lccc}
\hline & FAKTOR 1 & FAKTOR 2 & FAKTOR 3 \\
\hline FAKTOR 1 & 1,000 & 0,614 & 0,589 \\
FAKTOR 2 & 0,614 & 1,000 & 0,451 \\
FAKTOR 3 & 0,589 & 0,451 & 1,000 \\
\hline
\end{tabular}

Verder blyk dit dat drie werkswaardes hoog laai op Faktor 2, naamlik: lojaliteit $(0,759)$, deursigtigheid $(0,746)$ en konsekwentheid $(0,624)$. Weereens het aldrie werkswaardes beduidende ladings op Faktor 2. Faktor 2 is dus ook goed bepaal.

Laastens laai die volgende drie werkswaardes op Faktor 3: kliëntebehoefte-oriëntasie $(0,786)$, innovasie $(0,555)$ en afhandelingsingesteldheid $(0,337)$. Kliëntebehoefte-oriëntasie en innovasie laai hoog op Faktor 3, terwyl afhandelingsingesteldheid 'n lae lading op Faktor 3 het. Hierdie faktor is redelik goed bepaal. Verder blyk dit dat Faktore 1, 2 en 3 matig gekorreleerd is. Hierdie drie faktore verklaar $70,30 \%$ van die totale variansie van Skaal C.

Die betroubaarheid van Skaal C is 0,875 volgens Cronbach se koëffisiënt alfa.

Skale B en C het dus aanvaarbare psigometriese eienskappe.

Soos reeds genoem is Skale B en C ook gesamentlik aan 'n faktorontleding onderwerp. Die werkswaardes van Skale B en C is geinterkorreleer en die eigenwaardes van die ongereduseerde interkorrelasiematriks is bepaal.

Uit 'n inspeksie van die eigenwaardes van Skale B en C blyk dit dat ses eigenwaardes groter is as een. Vervolgens is ses faktore onttrek en na eenvoudige struktuur geroteer met behulp van die Direct Oblimin-rotasie.

Twee van die faktore was swak bepaal en gevolglik is vier faktore onttrek. Die geroteerde faktormatriks verskyn in Tabel 4 .

Vir die gemak van die leser sal daar voorts verwys word na (w) vir werklike werkswaardes en (i) vir ideale werkswaardes. Die werkswaardes wat matig tot hoog laai op Faktor 1 is soos volg: integriteit $(\mathrm{w})$, professionalteit $(\mathrm{w})$, uitnemendheid (w), konsekwentheid (w) en bevoegdheid (w). Hierdie faktor het betrekking op die persoonlike kwaliteite van akademici.

Die volgende werkswaardes het matige tot hoë ladings op Faktor 2: kliëntebehoefte-oriëntasie (w), kliëntebehoefteoriëntasie (i), afhandelingsingesteldheid (i), innovasie (w) en afhandelingsingesteldheid (w). Al hierdie werkswaardes, behalwe innovasie $(w)$ en afhandelingsingesteldheid $(w)$ het hoë ladings op Faktor 2. Laasgenoemde twee het matige ladings op Faktor 2. Hierdie faktor is dus goed bepaal. Dit het betrekking op die behoeftes van die "kliënte" van die akademici.

\section{TABeL 4}

GEROTEERDE FAKTORMATRIKS VAN SKALE B EN C GESAMENTLIK (DIRECT OBLIMIN-ROTASIE)

\begin{tabular}{|c|c|c|c|c|c|}
\hline & FAKTOR 1 & FAKTOR 2 & FAKTOR 3 & FACTOR 4 & $\mathbf{h}^{2} \mathbf{j}$ \\
\hline Professionaliteit (w) & 0,819 & 0,244 & $-0,171$ & 0,070 & 0,817 \\
\hline Integriteit (w) & 0,757 & 0,009 & $-0,041$ & 0,174 & 0,667 \\
\hline Uitnemendheid (w) & 0,706 & 0,051 & $+0,050$ & 0,112 & 0,613 \\
\hline Konsekwentheid (w) & 0,589 & $-0,104$ & $+0,359$ & 0,042 & 0,561 \\
\hline Bevoegdheid (w) & 0,558 & 0,022 & $+0,050$ & 0,314 & 0,555 \\
\hline Kliëntebehoefte-oriëntasie (w) & 0,233 & 0,815 & $-0,037$ & $-0,149$ & 0,725 \\
\hline Kliëntebehoefte-oriëntasie (i) & $-0,104$ & 0,701 & $-0,030$ & 0,104 & 0,507 \\
\hline Afhandelingsingesteldheid (i) & $-0,080$ & 0,471 & $+0,340$ & 0,070 & 0,433 \\
\hline Innovasie $(w)$ & 0,365 & 0,393 & $+0,159$ & $-0,020$ & 0,452 \\
\hline Afhandelingsingesteldheid (w) & 0,152 & 0,277 & $+0,150$ & 0,047 & 0,203 \\
\hline Lojaliteit (i) & $-0,020$ & 0,106 & $+0,718$ & 0,133 & 0,623 \\
\hline Lojaliteit (w) & 0,373 & $-0,020$ & $+0,631$ & $-0,112$ & 0,626 \\
\hline Deursigtig (w) & 0,490 & 0,152 & $+0,501$ & $-0,245$ & 0,659 \\
\hline Konsekwentheid (i) & 0,053 & $-0,002$ & $+0,464$ & 0,443 & 0,523 \\
\hline Deursigtig (i) & $-0,100$ & 0,238 & $+0,409$ & 0,271 & 0,399 \\
\hline Bevoegdheid (i) & 0,034 & $-0,040$ & $+0,090$ & 0,627 & 0,419 \\
\hline Integriteit (i) & 0,067 & 0,098 & $-0,040$ & 0,609 & 0,445 \\
\hline Uitnemendheid (i) & 0,217 & $-0,070$ & $-0,032$ & 0,502 & 0,325 \\
\hline Professionaliteit (i) & 0,148 & 0,296 & $-0,218$ & 0,372 & 0,346 \\
\hline Innovasie (i) & $-0,060$ & 0,192 & $+0,198$ & 0,322 & 0,250 \\
\hline
\end{tabular}

\section{INTERKORRELASIES VAN FAKTORE}

\begin{tabular}{lrrrr}
\hline & FAKTOR 1 & FAKTOR 2 & FAKTOR 3 & FACTOR 4 \\
\hline FAKTOR 1 & 1,000 & 0,293 & $+0,297$ & 0,299 \\
FAKTOR 2 & 0,293 & 1,000 & $+0,284$ & 0,365 \\
FAKTOR 3 & $+0,297$ & $+0,284$ & 1,000 & $+0,198$ \\
FAKTOR 4 & 0,299 & 0,365 & $+0,198$ & 1,000 \\
\hline
\end{tabular}

Nota: $\mathrm{I}$ = Geïdealiseerde werkswaardes

$\mathrm{W}=$ Werklike werkswaardes

Faktor 3 is in geheel gereflekteer

Faktor 3 is in sy geheel gereflekteer. Die werkswaardes wat hoog laai op Faktor 3 is soos volg: lojaliteit (i), lojaliteit (w), deursigtigheid (w), konsekwentheid (i) en deursigtigheid (i). Faktor 3 is dus goed bepaal. Dit het betrekking op die wyse waarop die "kliënte" gedien word.

Die volgende werkswaardes laai op Faktor 4: bevoegdheid (i), integriteit (i), uitnemendheid (i), professionaliteit (i) en innovasie (i). Al hierdie werkswaardes, behalwe professionaliteit (i) en innovasie (i) het hoë ladings op Faktor 4. Laasgenoemde twee werkswaardes het lae ladings op Faktor 4. Hierdie faktor is ook goed bepaal. Dit het betrekking op die geïdealiseerde persoonlike kwaliteite van dosente.

Faktore 1, 2, 3 en 4 is matig gekorreleer met mekaar.

Ten einde Hipotese 1 te toets, moes daar bepaal word of daar 'n verskil is tussen die werklike en geïdealiseerde werkswaardes. Vir 
TABeL 5

VERSKILLE IN GEMIDDELDES TUSSEN DIE IDEALE EN WERKLIKE WERKSWAARDES (SKALE B EN C)

\begin{tabular}{|c|c|c|c|c|c|c|}
\hline \multicolumn{2}{|c|}{ Veranderlike } & \multirow{2}{*}{$\begin{array}{l}\text { Gemiddelde Verskil } \\
\qquad \overline{\mathrm{X}}_{\mathrm{v}} \\
-0,020\end{array}$} & \multirow{2}{*}{$\begin{array}{c}\text { Standaard-Afwyking } \\
\text { SA } \\
1,270\end{array}$} & \multirow{2}{*}{$\begin{array}{c}\mathbf{t} \text {-waarde } \\
\mathbf{t} \\
-0,214\end{array}$} & \multirow{2}{*}{$\begin{array}{c}\begin{array}{c}\text { Grade van vryheid } \\
\text { gv }\end{array} \\
120\end{array}$} & \multirow{2}{*}{$\begin{array}{c}\begin{array}{c}\text { Beduidendheidspeil } \\
\mathbf{p}\end{array} \\
0,831\end{array}$} \\
\hline 1 & $\begin{array}{l}\text { Afhandelingsingesteldheid (i) - } \\
\text { Afhandelingsingesteldheid (w) }\end{array}$ & & & & & \\
\hline 2 & $\begin{array}{l}\text { Kliëntebehoefte-oriëntasie (i) - } \\
\text { Kliëntebehoefte-oriëntasie (w) }\end{array}$ & 0,098 & 1,180 & 0,920 & 121 & 0,360 \\
\hline 3 & $\begin{array}{l}\text { Professionaliteit (i) - } \\
\text { Professionaliteit (w) }\end{array}$ & 0,340 & 0,960 & 3,960 & 121 & $<0,001^{*}$ \\
\hline 4 & $\begin{array}{l}\text { Integriteit (i) - } \\
\text { Integriteit (w) }\end{array}$ & 0,350 & 1,100 & 3,546 & 121 & 0,001 * \\
\hline 5 & $\begin{array}{l}\text { Innovasie (i) - } \\
\text { Innovasie (w) }\end{array}$ & 0,700 & 1,230 & 6,244 & 121 & $<0,001$ * \\
\hline 6 & $\begin{array}{l}\text { Uitnemendheid (i) - } \\
\text { Uitnemendheid (w) }\end{array}$ & 0,520 & 1,010 & 5,669 & 121 & $<0,001$ * \\
\hline 7 & $\begin{array}{l}\text { Deursigtigheid (i) - } \\
\text { Deursigtigheid (w) }\end{array}$ & 0,320 & 1,490 & 2,370 & 121 & $0,019^{*}$ \\
\hline 8 & $\begin{array}{l}\text { Lojaliteit (i) - } \\
\text { Lojaliteit (w) }\end{array}$ & 0,033 & 1,190 & 0,306 & 120 & 0,760 \\
\hline 9 & $\begin{array}{l}\text { Konsekwentheid (i) - } \\
\text { Konsekwentheid (w) }\end{array}$ & 0,290 & 1,120 & 2,837 & 121 & $0,005^{*}$ \\
\hline 10 & $\begin{array}{l}\text { Bevoegdheid (i) - } \\
\text { Bevoegdheid (w) }\end{array}$ & 0,420 & 0,960 & 4,806 & 121 & $<0,001 *$ \\
\hline
\end{tabular}

Nota:

* - Statisties-beduidend

$\bar{X}_{\mathrm{v}}$ - Verskil in gemiddeldes tussen geidealiseerde en werklike werkswaardes

hierdie doel is daar van t-toetse vir afhanklike groepe gebruik gemaak. Die verskille in gemiddeldes tussen die geidealiseerde en werklike werkswaardes verskyn in Tabel 5.

Dit blyk dat slegs drie van die werkswaardes nie statistiesbeduidend verskil nie, te wete: afhandelingsingesteldheid, kliëntebehoefte-oriëntasie en lojaliteit.

Ten einde Hipotese 2 te toets is afsonderlike ontledings ten opsigte van Skale $\mathrm{B}$ en $\mathrm{C}$ gedoen vir die verskillende demografiese veranderlikes.

Verskillende subgroepe is gevorm aan die hand van die demografiese veranderlikes. Hierdie subgroepe is vergelyk ten opsigte van die verskillende werkswaardes. Waar drie of meer groepe vergelyk is, is konsekwent eers 'n meerveranderlike variansieontleding gedoen om vas te stel of die verskillende groepe onderling van mekaar verskil. Dit is opgevolg deur eenrigtingvariansieontledings en Scheffé of Dunnett se post hoc meervoudige vergelykings. By die meerveranderlike variansieontleding is daar deurgaans van vier statistieke gebruik gemaak, naamlik Pillais se spoor, Wilks se lambda, Hotelling se spoor en Roy se grootste wortel. Hierdie indekse is gebruik om te toets of die vektore van gemiddeldes statisties-beduidend van mekaar verskil al dan nie. 'n Voorbeeld van die verskillende indekse verskyn in Tabel 6 .

Alhoewel hierdie vier indekse normaalweg eenduidig is, blyk dit uit die volgende resultate dat Roy se grootste wortel soms beduidend is terwyl die ander deurgaans op nie-beduidendheid dui. Roy se indeks is stellig minder streng as die ander drie indekse. Daar sal voorts na Roy se grootste wortel verwys word ten einde die beduidenheid van die verskille, al dan nie, aan te dui. Waar slegs twee groepe met mekaar vergelyk is, is konsekwent van Hotelling se $\mathrm{T}^{2}$ gebruik gemaak, gevolg deur t-toetse.

Die demografiese veranderlikes wat gebruik is, is fakulteit, rang, geslag, taal en ouderdom. Daar is van die groeperings gebruik gemaak soos in Tabel 1 aangedui. Die resultate word eers vir Skaal B en daarna vir Skaal C gegee.
Daar sal eers na die geïdealiseerde werkswaardes gekyk word.

Geïdealiseerde werkswaardes

TABel 6

EENRIGTINGVARIANSIEONTLEIDING:

VERGELYKING VAN DIE GË̈DEALISEERDE WERKSWAARDES T.O.V. DIE VERSKILLENDE FAKULTEITE

\begin{tabular}{lrrrrr}
\hline $\begin{array}{l}\text { Bron Afhanklike veranderlike: } \\
\text { Ideale werkswaardes }\end{array}$ & $\begin{array}{c}\text { Tipe III } \\
\text { Som van } \\
\text { kwadrate }\end{array}$ & $\begin{array}{c}\text { gv } \\
\text { Kwadrate }\end{array}$ & Femiddelde & P(F) \\
\hline Afhandelingsingesteldheid & 3,88 & 3 & 1,263 & 0,942 & 0,423 \\
Kliëntebehoefte-oriëntasie & 4,077 & 3 & 1,359 & 0,865 & 0,461 \\
Professionaliteit & 1,042 & 3 & 0,347 & 0,665 & 0,575 \\
Integriteit & 1,640 & 3 & 0,547 & 1,261 & 0,291 \\
Innovasie & 4,297 & 3 & 1,432 & 1,411 & 0,243 \\
Uitnemendheid & 2,133 & 3 & 0,711 & 1,338 & 0,266 \\
Deursigtigheid & 5,367 & 3 & 1,789 & 1,146 & 0,334 \\
Lojaliteit & 8,678 & 3 & 2,893 & 1,346 & 0,263 \\
Konsekwentheid & 8,997 & 3 & 2,999 & 3,516 & $0,018 *$ \\
Bevoegdheid & 0,932 & 3 & 0,311 & 0,701 & 0,554 \\
\hline
\end{tabular}

Nota: Die meerveranderlike variansieontleding het volgens Roy se Grootste Wortel 'n waarde van 0,217 opgelewer, met 'n geassosieerde $F(10,102)=2,217 ; p=0,022$.

In die vergelyking van fakulteite ten opsigte van die geïdealiseerde werkswaardes was Roy se grootste wortel $0,217\left[\mathrm{~F}_{(\mathrm{gv}=10,102)}=2,217\right.$; $\mathrm{p}=0,022]$. Dit dui daarop dat daar wel statisties-beduidende verskille in die geheel is. Wat die eenrigtingvariansieontleding betref, was daar slegs een veranderlike wat statisties beduidend was, naamlik konsekwentheid. Dit mag bloot toevallig wees, maar 
word nogtans uitgelig. Geen verdere vergelykings ten opsigte van hierdie veranderlikes is gedoen nie.

Waar die geïdealiseerde werkswaardes ten opsigte van range vergelyk is, was Roy se grootste wortel $0,199\left[\mathrm{~F}_{(\mathrm{gv}}=10,110\right)=$ $2,189 ; p=0,023]$. Dit dui daarop dat daar wel statistiesbeduidende verskille in die geheel is. By nadere ondersoek het dit egter geblyk dat daar slegs een veranderlike is wat beduidend is, naamlik integriteit. Dit mag bloot toevallig wees, maar word nogtans uitgelig. Daar is geen verdere vergelykings gedoen ten opsigte van dié bepaalde veranderlike nie.

In die vergelyking van die geïdealiseerde werkswaardes ten opsigte van geslag was Roy se grootste wortel $0,125\left[\mathrm{~F}_{(\mathrm{gv}}=10,108\right)$ $=1,349 ; \mathrm{p}=0,214]$. Dit dui op geen statisties-beduidende verskille in die geheel nie. Gevolglik is daar geen verdere vergelykings gedoen ten opsigte van hierdie veranderlike nie.

In die vergelyking van die geidealiseerde werkswaardes ten opsigte van huistaal was Roy se grootste wortel $0,051\left[\mathrm{~F}_{(\mathrm{gv}=10,113)}=0,581\right.$; $p=0,827]$. Dit dui daarop dat daar nie statisties-beduidende verskille in die geheel is nie. Gevolglik is daar geen verdere vergelykings gedoen ten opsigte van hierdie veranderlike nie.

Waar die geïdealiseerde werkswaardes ten opsigte van ouderdom vergelyk is, was Roy se grootste wortel $0,139[\mathrm{~F}(\mathrm{gv}=10,100)=$ 1,387; $p=0,197]$. Dit dui op geen statisties-beduidende verskille in die geheel nie. Gevolglik is daar geen verdere vergelykings gedoen ten opsigte van hierdie veranderlike nie.

Vervolgens is die werklike werkswaardes onder die loep geneem.

\section{Werklike werkswaardes}

In die vergelyking van die werklike werkswaardes ten opsigte van fakulteit, was Roy se grootste wortel $0,180\left[\mathrm{~F}_{(\mathrm{gv}}=10,100\right)=$ $1,800 ; p=0,070]$. Dit dui weereens op geen statisties-beduidende verskille in die geheel nie. Gevolglik is daar geen verdere vergelykings gedoen ten opsigte van hierdie veranderlike nie.

In die vergelyking van die werklike werkswaardes ten opsigte van range, was Roy se grootste wortel $0,348\left[\mathrm{~F}_{(\mathrm{gv}=10,108)}=3,762\right.$; $p<0,001]$. Aangesien dit wel op 'n statisties-beduidende verskil in die geheel dui, is voortgegaan met die eenrigtingvariansieontleding en die Scheffétoetse. Volgens die Scheffétoets is daar geen verdere statisties-beduidende verskille gevind nie.

Waar die werklike werkswaardes ten opsigte van geslag vergelyk is, was Roy se grootste wortel $0,111\left[\mathrm{~F}_{(\mathrm{gv}}=10,107\right)=1,192 ; \mathrm{p}=$ $0,304]$. Aangesien dit nie op statisties-beduidende verskille in die geheel dui nie, is daar geen verdere vergelykings gedoen ten opsigte van hierdie veranderlike nie.

In die vergelyking van die werklike werkswaardes ten opsigte van huistaal was Roy se grootste wortel $0,126\left[\mathrm{~F}_{(\mathrm{gv}=10,111)}=1,397\right.$; $p=0,191]$. Dit dui op geen statisties-beduidende verskille nie, gevolglik is geen verdere vergelykings gedoen ten opsigte van hierdie veranderlike nie.

Waar die werklike werkswaardes ten opsigte van ouderdom vergelyk is, was Roy se grootste wortel $0,220\left[\mathrm{~F}_{(\mathrm{gv}=10,99)}=2,175\right.$; $p=0,025]$. Dit dui daarop dat daar 'n statisties-beduidende verskil in die geheel is. Uit die eenrigtingvariansieontleding blyk dit verder dat daar verskeie veranderlikes is wat statistiesbeduidend is. Hierdie resultate verskyn in Tabel 7. Die resultate van Scheffé en Dunnett se meervoudige vergelykings verskyn in Tabel 8.

TABEL 7

EENRIGTINGVARIANSIEONTLEIDING:

VERGELYKING VAN DIE WERKLIKE WERKSWAARDES VAN DIE VERSKILLENDE OUDERDOMSGROEPE

\begin{tabular}{|c|c|c|c|c|c|c|}
\hline Bron & $\begin{array}{l}\text { Afhanklike veranderlike: } \\
\text { Ideale werkswaardes }\end{array}$ & $\begin{array}{l}\text { Tipe III } \\
\text { Som van } \\
\text { kwadrate }\end{array}$ & gv & $\begin{array}{l}\text { Gemiddelde } \\
\text { Kwadrate }\end{array}$ & $\mathbf{F}$ & $\mathbf{P}(\mathbf{F})$ \\
\hline \multirow{10}{*}{ 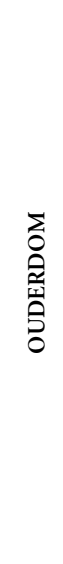 } & Afhandelingsingesteldheid & 11,026 & 2 & 5,513 & 4,118 & 0,019 * \\
\hline & Kliëntebehoefte-oriëntasie & 6,308 & 2 & 3,154 & 1,955 & 0,147 \\
\hline & Professionaliteit & 2,559 & 2 & 1,280 & 1,333 & 0,268 \\
\hline & Integriteit & 5,486 & 2 & 2,743 & 2,047 & 0,134 \\
\hline & Innovasie & 19,608 & 2 & 9,804 & 5,605 & 0,005 * \\
\hline & Uitnemendheid & 12,643 & 2 & 6,322 & 5,780 & 0,004 * \\
\hline & Deursigtigheid & 21,656 & 2 & 10,828 & 4,932 & 0,009 * \\
\hline & Lojaliteit & 11,088 & 2 & 5,544 & 3,001 & 0,054 \\
\hline & Konsekwentheid & 12,176 & 2 & 6,088 & 4,412 & 0,014 * \\
\hline & Bevoegdheid & 4,411 & 2 & 2,206 & 2,001 & 0,140 \\
\hline
\end{tabular}

Nota: Die meerveranderlike variansieontleding het volgens Roy se Grootste Wortel ' $\mathrm{n}$ waarde van 0,022 opgelewer, met ' $n$ geassosieerde $F(10,99)=2,175 ; p=0,025$.

Die groepsgemiddelde ten opsigte van die volgende veranderlikes verskil onderling: afhandelingsingesteldheid, innovasie, uitnemendheid, deursigtigheid en konsekwentheid. Dit mag bloot toevallig wees, maar word wel uitgelig. Daar is volgens die Scheffétoets 'n statisties-beduidende verskil in afhandelingsingesteldheid tussen die ouderdomsgroepe 36 jaar en jonger en 49 jaar en ouer waar die ouderdomsgroep 49 jaar en ouer, 'n hoër gemiddelde het. Wat innovasie betref. dui die Scheffétoets daarop dat die verskil tussen die ouderdomme van 36 en jonger, en 49 jaar en ouer lê. Die ouderdomsgroep van 49 jaar en ouer het weereens die hoër gemiddeld. Verder is daar ook statisties-beduidende verskille deur die Dunnett-toets

TABel 8

SCHEFFé EN DUNNETT SE MEERVOUdGE VERGELYKINGS: VERGELYKING VAN DIE WERKSWAARDES VAN DIE VERSKILLENDE OUDERDOMSGROEPE

\begin{tabular}{|c|c|c|c|c|c|c|c|c|c|}
\hline \multirow[t]{2}{*}{ Werkswaardes } & \multicolumn{3}{|c|}{ Groep gemiddeldes } & \multicolumn{3}{|c|}{ Standaardafwykings } & \multicolumn{3}{|c|}{ Groepvergelykings } \\
\hline & 1 & 2 & 3 & 1 & 2 & 3 & $1 / 2$ & $1 / 3$ & $2 / 3$ \\
\hline Afhandelingsingesteldheid & 5,26 & 5,89 & 5,72 & 1,36 & 1,06 & 1,04 & & $0,036^{*}$ & \\
\hline Innovasie & 4,69 & 5,21 & 5,73 & 1,28 & 1,42 & 1,26 & & $0,005^{*}$ & \\
\hline Uitnemendheid & 5,60 & 5,82 & 6,41 & 1,24 & 1,09 & 0,76 & & $0,005^{*}$ & 0,024 * \\
\hline Deursigtigheid & 4,57 & 4,95 & 5,65 & 1,65 & 1,47 & 1,32 & & 0,011 * & \\
\hline Konsekwentheid & 5,43 & 5,55 & 6,19 & 1,09 & 1,33 & 1,08 & & $0,026^{*}$ & \\
\hline
\end{tabular}

Nota: $1-36$ jaar en jonger

2 - tussen 37 en 49 jaar

3 - 49 jaar en ouer

* - statisties-beduidend 
aangedui ten opsigte van uitnemendheid tussen die ouderdomsgroepe 36 en jonger, en 49 jaar en ouer (die groep van 49 jaar en ouer het die hoër gemiddelde), en die ouderdomsgroep van tussen 37 en 49 jaar, en 49 jaar en ouer (weereens die groep van 49 jaar en ouer met die hoër gemiddeld). Na aanleiding van die Scheffétoets is daar 'n statisties-beduidende verskil ten opsigte van deursigtigheid tussen die ouderdomsgroepe van 36 jaar en jonger, en 49 jaar en ouer, waar die groep van 49 jaar en ouer die hoër gemiddeld het. Laastens dui die Scheffétoets ook op 'n statistiesbeduidende verskil ten opsigte van konsekwentheid tussen die ouderdomsgroepe van 36 jaar en jonger, en 49 jaar en ouer, waar die groep van 49 en ouer weereens 'n hoër gemiddeld het.

Skaal A is gebruik om die relatiewe sterkte van werkswaardes binne die geledere van akademici te bepaal. Die werkswaardes is geskaleer vir die verskillende fakulteite afsonderlik en koëffisiënte van profieleendersheid is tussen die fakulteite bereken. Voorts is koëffisiënte van profieleendersheid ook bereken ten opsigte van Skale B en C. Hierdie koëffisiënte van profieleendersheid verskyn in Tabel 9. Die skaalwaardes ten opsigte van die vier fakulteite word grafies uitgebeeld in Figuur 1.

TABel 9

Kö̈FFISIËNTE VAN PROFIELEENDERSHEID TUSSEN FAKULTEITE TEN OPSIGTE VAN SKALE A, B EN C

\begin{tabular}{|c|c|c|c|c|}
\hline SKAAL A & $\begin{array}{c}\text { Ekonomiese en } \\
\text { Bestuurswetenskappe }\end{array}$ & $\begin{array}{c}\text { Ingenieurswese/ } \\
\text { Natuurwetenskappe }\end{array}$ & $\begin{array}{c}\text { Lettere en } \\
\text { Wysbegeerte }\end{array}$ & $\begin{array}{l}\text { Opvoedkunde en } \\
\text { Verpleegkunde }\end{array}$ \\
\hline Ekonomiese en Bestuurswetenskappe & 1 & & & \\
\hline Ingenieurswese/Natuurwetenskappe & 0,838 & 1 & & \\
\hline Lettere en Wysbegeerte & 0,903 & 0,975 & 1 & \\
\hline Opvoedkunde en Verpleegkunde & 0,935 & 0,863 & 0,896 & 1 \\
\hline SKAAL B & $\begin{array}{c}\text { Ekonomiese en } \\
\text { Bestuurswetenskappe }\end{array}$ & $\begin{array}{l}\text { Ingenieurswese/ } \\
\text { Natuurwetenskappe }\end{array}$ & $\begin{array}{c}\text { Lettere en } \\
\text { Wysbegeerte }\end{array}$ & $\begin{array}{l}\text { Opvoedkunde en } \\
\text { Verpleegkunde }\end{array}$ \\
\hline Ekonomiese en Bestuurswetenskappe & 1 & & & \\
\hline Ingenieurswese/Natuurwetenskappe & 0,912 & 1 & & \\
\hline Lettere en Wysbegeerte & 0,792 & 0,924 & 1 & \\
\hline Opvoedkunde en Verpleegkunde & 0,864 & 0,966 & 0,873 & 1 \\
\hline SKAAL C & $\begin{array}{c}\text { Ekonomiese en } \\
\text { Bestuurswetenskappe }\end{array}$ & $\begin{array}{c}\text { Ingenieurswese/ } \\
\text { Natuurwetenskappe }\end{array}$ & $\begin{array}{c}\text { Lettere en } \\
\text { Wysbegeerte }\end{array}$ & $\begin{array}{l}\text { Opvoedkunde en } \\
\text { Verpleegkunde }\end{array}$ \\
\hline Ekonomiese en Bestuurswetenskappe & 1 & & & \\
\hline Ingenieurswese/Natuurwetenskappe & 0,847 & 1 & & \\
\hline Lettere en Wysbegeerte & 0,805 & 0,898 & 1 & \\
\hline Opvoedkunde en Verpleegkunde & 0,847 & 0,792 & 0,930 & 1 \\
\hline
\end{tabular}
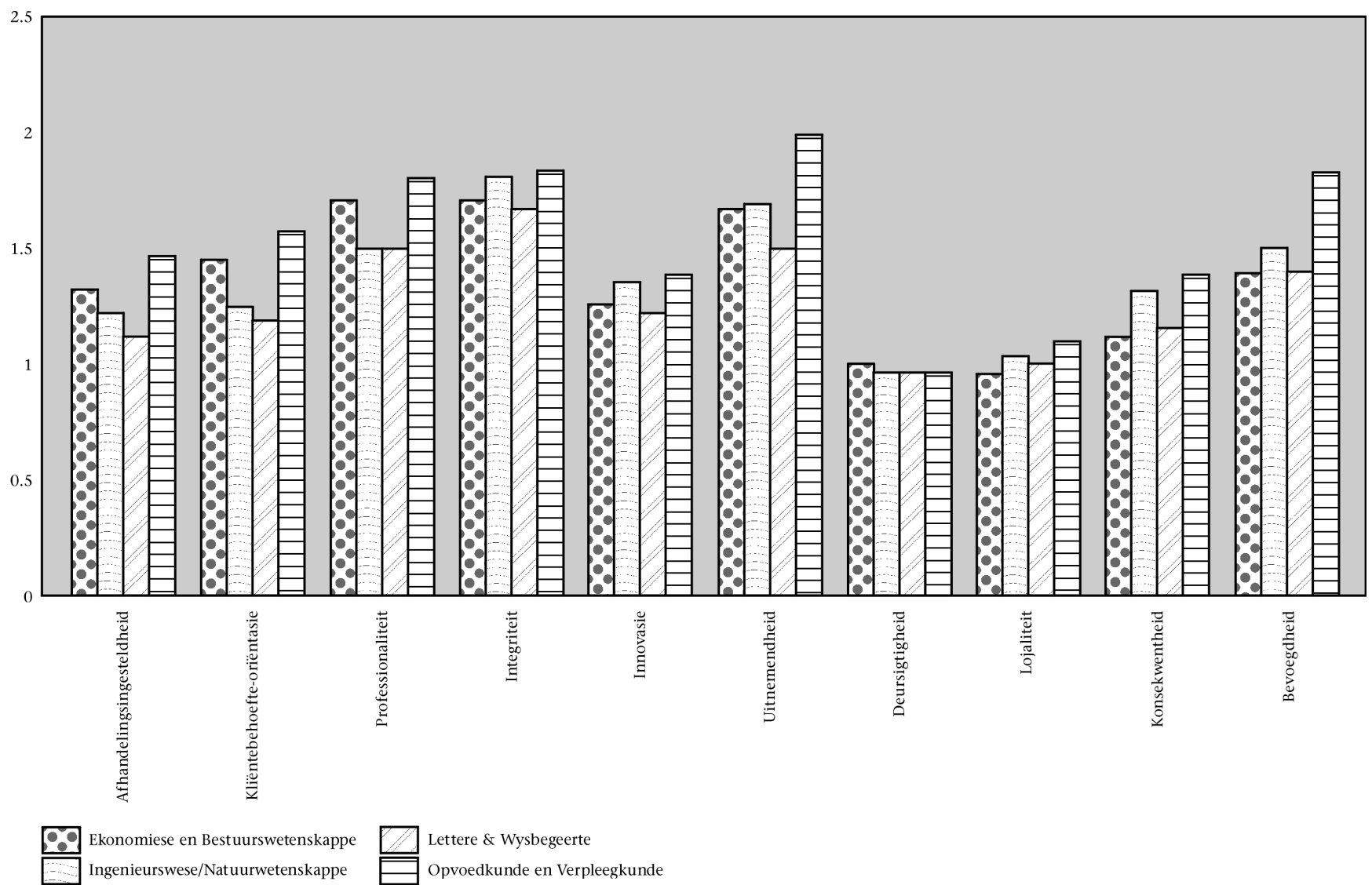

Figuur 2: Skaalwaardes ten opsigte van die verskillende fakulteite 
Ten einde Hipotese 3 te toets, is die skaalwaardes vir elke fakulteit met mekaar gekorreleer. Dit is gedoen vir Skale A, B en C. Uit ' $n$ inspeksie van Tabel 10 blyk dit dat die profiele van die werkswaardes van die vier fakulteite baie eenders is.

Laastens is die rangordes van die werkswaardes aan die hand van Skale A, B en C bepaal. Hierdie resultate word weergegee in Tabel 10. Die doel hiervan was om te wys hoe die werkswaardes ooreenstem en/of verskil vir die totale groep. Deurgaans is die werkswaarde integriteit aangedui as die belangrikste waarde en die werkswaarde deursigtigheid as van minste belang.

TABEL 10

RANGORDES VAN WERKSWAARDES VIR DIE STEEKPROEF AS GEHEEL TEN OPSIGTE VAN SKALE A, B EN C

\begin{tabular}{lcccccc}
\hline & Skaal A & $\begin{array}{c}\text { Rang } \\
\text {-orde }\end{array}$ & Skaal B & $\begin{array}{c}\text { Rang } \\
\text {-orde }\end{array}$ & Skaal C & $\begin{array}{c}\text { Rang } \\
\text {-orde }\end{array}$ \\
\hline Afhandelingsingesteldheid & 1,214 & 8 & 5,672 & 7 & 5,692 & 6 \\
Kliëntebehoefte-oriëntasie & 1,287 & 5 & 5,664 & 8 & 5,554 & 7 \\
Professionaliteit & 1,583 & 2 & 6,574 & 3 & 6,207 & 2 \\
Integriteit & 1,760 & 1 & 6,615 & 1 & 6,248 & 1 \\
Innovasie & 1,285 & 6 & 5,967 & 6 & 5,240 & 9 \\
Uitnemendheid & 1,566 & 3 & 6,467 & 4 & 5,950 & 4 \\
Deursigtigheid & 1,000 & 10 & 5,475 & 10 & 5,132 & 10 \\
Lojaliteit & 1,042 & 9 & 5,508 & 9 & 5,475 & 8 \\
Konsekwentheid & 1,262 & 7 & 5,992 & 5 & 5,694 & 5 \\
Bevoegdheid & 1,460 & 4 & 6,582 & 2 & 6,182 & 3 \\
\hline
\end{tabular}

Die betroubaarheid van Skaal A is volgens Cronbach se koëffisiënt alfa was 0,901 .

\section{BESPREKING}

Die resultate dui daarop dat in terme van die werkswaardes soos gemeet deur Skale B en C, die volgende afgelei kan word: Die faktore wat weërspieël word in die faktormatriks (Tabel 4) sal eerstens bespreek word. Die faktore professionaliteit (w), integriteit (w), uitnemendheid (w), konsekwentheid (w) en bevoegdheid (w), laai hoog op Faktor 1 en kan dus beskryf word as die werkswaardes wat betrekking het op die werklike attribute van akademici. Faktor 2 kan beskryf word as die werkswaardes van akademici wat betrekking het op die kliënt se behoeftes, naamlik kliëntebehoefte-oriëntasie (w), kliëntebehoefte-oriëntasie (i), afhandelingsingesteldheid (i), innovasie (w) en afhandelingsingesteldheid (w). Faktor 3 meet weer die werkswaardes wat gefokus is op die kollegealiteit van akademici, naamlik: lojaliteit (i), lojaliteit (w), deursigtigheid (w), konsekwentheid (i) en deursigtigheid (i). Faktor 4 meet dié werkwaardes wat gefokus is op die idealistiese attribute van akademici en is die volgende, bevoegdheid (i), integriteit (i), uitnemendheid (i), professionaliteit (i) en innovasie (i).

$\mathrm{Na}$ aanleiding van die navorsing kan die vraag gevra word of daar enige inherente verskille bestaan tussen die geïdealiseerde en die werklike werkswaardes soos gemeet deur Skale B en C. Daar is bevind dat daar statisties-beduidende verskille ten opsigte van sewe van die tien werkswaardes is, naamlik professionaliteit, integriteit, innovasie, uitnemendheid, deursigtigheid, konsekwentheid en bevoegdheid. Dit dui daarop dat akademici besef dat die werkswaardes wat tans van belang is, nie noodwendig die waardes is wat onder ideale omstandighede of in die toekoms van belang sal wees nie. Die rede hiervoor mag wees dat in terme van die veranderinge wat tans in die hoër onderwys plaasvind, daar 'n bewuswording by akademici geskep word dat die huidige werkswaardes aangepas sal moet word ten einde die transformasieproses ten volle te ondersteun. Hierdie bevindinge verleen sterk steun aan die verwagting gestel in Hipotese 1, naamlik dat daar wel statisties-beduidende verskille tussen die werklike en geïdealiseerde werkswaardes van akademici bestaan.

Die tweede vraag wat gevra kan word, is hoe die werkswaardes verskil in terme van die demografiese agtergrond van die akademici. Dit blyk dat daar ten opsigte van die geïdealiseerde werkswaardes in die geheel 'n verskil bestaan tussen fakulteite ten opsigte van konsekwentheid en ook tussen range ten opsigte van integriteit. Die post hoc meervoudige vergelykings kon egter nie die oorsprong van die verskille bepaal nie.

Daar is ook statisties-beduidende verskille ten opsigte van die werklike werkswaardes van verskillende ouderdomsgroepe. Daar is bevind dat die verskille konsekwent voorkom in terme van die ouderdomsgroepe 36 jaar en jonger, en 49 jaar en ouer, waar die 49 jaar en ouer groep oorwegend sterker voel oor die volgende werkswaardes: afhandelingsingesteldheid, innovasie, uitnemendheid, deursigtigheid en konsekwentheid. Daar is ook 'n statisties-beduidende verskil ten opsigte van uitnemendheid tussen die ouderdomsgroepe 37 tot 49 jaar, en 49 jaar en ouer. ' $n$ Moontlike verduideliking hiervoor mag wees dat ouer akademici reeds oor 'n gekristalliseerde werkswaardestelsel beskik en ook oor meer werkservaring, terwyl junior akademici se werkswaardestelsels nog in 'n proses van vorming is. Dié siening word ondersteun deur Bode (1997) wat stel dat individue nie met 'n waardestelsel gebore word nie, maar dat die waardes gevorm en ontwikkel word deur die omgewing en lewenservaring. Verder is gevind dat daar geen verskil in die geheel is in terme van fakulteite, range, geslag en taal ten opsigte van die werklike werkswaardes is nie. Dit dui daarop dat die tersiêre instelling 'n gemeenskaplike en ooreenstemmende basis van sterk gevormde waardes by akademici kweek.

Hierdie bevinding ondersteun dus die verwagting van Hipotese 2 gedeeltelik, naamlik dat daar wel statisties-beduidende verskille bestaan tussen die werkswaardes van akademici uit verskillende fakulteite, geslagsgroepe, range, huistale en ouderdomsgroepe. Die bevinding mag wel anders gelyk het indien die steekproef uit meer as een inrigting bestaan het. Dit kan as 'n beperking van die studie genoem word. 'n Wyer steekproef, gefokus op ander tersiêre instellings, sou tot 'n ryker datastel gelei het.

Die derde vraag wat ontstaan uit die studie is hoe die relatiewe sterktes van die werkswaardes lyk vir elke fakulteit afsonderlik en vir die universiteit as geheel. Die relatiewe sterkte van die werkswaardes per fakulteit is hoog. Die skaalwaardes vir die fakulteite afsonderlik stem ook sterk ooreen. Die enigste fakulteit wat effens van die ander verskil is Opvoedkunde en Verpleegkunde. Die hoogste korrelasie kom deurgaans voor tussen die Fakulteit Lettere en Wysbegeerte en die Fakulteite Ingenieurswese/Natuurwetenskappe. Dit mag egter wees omdat die funksionering van dié fakulteite ietwat verskil van die ander. Dieselfde werkswaardes is deurgaans ewe belangrik en verskil nie tussen die fakulteite nie. Dié bevinding dui op hoë profieleendersheid tussen die vier fakulteite. Dit dui daarop dat akademici dieselfde waardes onderskryf en dat die waardestelsel konsekwent is. Hipotese 3 stel dat daar nie profieleendersheid onder die fakulteite (afsonderlik en gesamentlik) in terme van werkswaardes bestaan nie. Dit blyk nie die geval te wees nie, gevolglik word Hipotese 3 nie gesteun nie.

Laastens kan die vraag gevra word wat die rangordes is waarin die werkswaardes vir die totale groep geplaas word. Daar word gevra of die metings van Skale A, B en C ooreenstem of verskil van mekaar. Deurgaans is integriteit aangedui as die belangrikste werkswaarde en deursigtigheid as die minste belangrik. Die skale meet dus dieselfde in terme van die belangrikheid van waardes.

Soos reeds genoem, kan die feit dat die steekproef slegs uit een inrigting getrek is, as 'n leemte van die studie beskou word. 'n 
Verdere beperking van die studie is die klein steekproef. Behalwe dat die responskoers aanvanklik laag was, het onvolledige vraelyste ook voorgekom. Dit kan moontlik daaraan toegeskryf word dat respondente steeds bang was dat hulle geïdentifiseer sou kon word aan die hand van biografiese inligting.

Die resultate van die betrokke studie dui daarop dat dit suksesvol was in terme van al die metings wat gedoen is. Aldrie die meetinstrumente wat gebruik is, het hoë betroubaarhede opgelewer.

Aangesien hierdie studie ' $n$ unieke fokus gehad het en in ' $n$ baie spesifieke omgewing en op 'n spesifieke steekproef toegepas is, kan dit nie die leemtes van vorige navorsing aanspreek nie. Daar is ook nie vorige navorsing op hierdie gebied gedoen nie. Die navorsing was egter geregverdig deurdat tersiêre instellings die meetinstrumente vir verdere navorsing sal kan aanwend. 'n Voorstel vir verdere navorsing is om 'n vergelyking te tref tussen die metings van Skaal A (Torgerson se Konstante-Som-Metode) en Skaal B en Skaal C (normatiewe instrumente). Daar kan ook verdere studies gedoen word op akademici van ander tersiêre inrigtings om sodoende die steekproef te vergroot.

\section{VERWYSINGS}

Allport, G.W. (1961). Pattern and growth in personality. New York: Holt, Rinehart \& Winston.

Allport, G.W., Vernon, P.E. \& Lindzey, G. (1960). Study of values. Boston: Houghton Mifflen Co.

Bode, B. (1997). Norming, the South African Work Value Questionnaire. Ongepubliseerde Magister Artium proefskrif. Randse Afrikaanse Universiteit, Johannesburg.

Braithwaite, V.A. \& Law, H.G. (1985). Structure of human values: Testing the adequacy of the Rokeach value survey. Journal of Personality and Social Psychology, 49 (1), 250-263.

Elizur, D. (1996). Work values and commitment. International Journal of Manpower, 17 (3), 20-25.

Emmet, G.M. (1988). The influence of work values on career development. Ongepubliseerde Magister Artium Proefskrif. Randse Afrikaanse Universiteit, Johannesburg.

Feather, N.T. (1973). The measurement of values: Effects of different assessment procedures. Australian Journal of Psychology, 25 (3), 221-231.

Flowers, J. (1988). Die invloed van geslag en etnisiteit op werkwaardes. Journal of Industrial Psychology, 14 (1), 5-11.

Gorsuch, R.L. (1970). Rokeach's approach to value systems and social compassion. Review of Religious Research, 11, 139-143.

Hattingh, L. (1991). 'n Teorie van waardes. 'n Ongepubliseerde D. Ed.-proefskrif. Johannesburg: RAU.

Hoelsen, C.N. \& Stead, G.B. (1998). Construct validation of Joubert's Value Orientation Measure. Journal of Industrial Psychology, 24 (1), 1-4.

Hofstede, G. (1980). Culture's concequences: International differences in work-related values. Beverly Hills, CA: Sage.

Hofstede, G. (1998). Attitudes, values and organisational culture; disentangling the concepts. Organisation Studies, 19 (3), 477492.

Hofstede, G. \& Bond, M.H. (1984). Hofstede's culture dimensions: An independent validation using Rokeach's value survey. Journal of Cross-Cultural Psychology, 15 (4), 417433.

Hugo, A. \& van Vuuren, L.J. (1996). A cross-cultural analysis of work values and moral reasoning. Journal of Industrial Psychology, 22 (1), 12-18.

James, W. (2000). Values, education and democracy. An unpublished report of the working group on values in education, Gauteng.

Kamakura, W.A. \& Mazzon, J.A. (1991). Value segmentation: A model for the measurement of values and value systems. Journal of Consumer Research, 18 (9), 208-218.

Kamakura, W.A. \& Novak, T.P. (1992). Value-system segmentation: Exploring the meaning of LOV. Journal of Consumer Research, 19 (6), 119-132.
Katzell, R.A. (1964). Personal values, job satisfaction and job behaviour. Man in a world of work. Borow, H. (Ed) Boston: Houghton Mifflin Co.

Kruger, T. \& Roodt, G. (2003). Hofstede's VSM-94 revisited: Is it reliable and valid? SA Journal of Industrial Psychology, 29 (1), 75-83.

Levy, S. \& Guttman, L. (1974). Values and attitudes of Israeli high school youth. Jerusalem: Institute of Applied Social Research.

Lusk, E.J. \& Olivier, B.L. (1974). American manager's personal value systems - revisited. Academy of Management Journal, $17,549-554$.

Maslow, A.H. (Ed.) (1959). New knowledge in human values. New York: Harper.

Mindell, M.G. \& Gorden, W.I. (1981). Employee values in a changing society, Reading, MA: Addison - Wesley Publishing Company.

Morris, C.W. (1956). Varieties of human value. Chicago: University of Chicago Press.

Oosthuizen, B. (1996). Werkwaardes en loopbaanankers as voorspellers van werksprestasie en werkstevredenheid. Ongepubliseerde Magister Artium Proefskrif. Universiteit van die Oranje Vrystaat, Bloemfontein.

Pepper, S.C. (1958). The sources of value. Berkeley: University of California Press.

Pietrofesa, J.J., Bernstein, B., Minor, J. \& Stanford, S. (1980). Guidance and introduction. Chicago: Rand McNally.

Rokeach, M. (1973). The nature of human values. New York: Free Press

Roodt, G. (1991). Die graad van werkbetrokkenheid as 'n voorspeller van persoonlike welsyn. 'n Studie by bestuurders. Bloemfontein: UOVS.

Rossouw, D. (1996). Waardes wat werk [Intyds]. Onttrek van die wêreldwye web: http://general.rau.ac.za/aambeeld/ november1996/waardes.html.

Republiek van Suid-Afrika. (1996). National commission on higher education. An overview of a new policy framework for higher education transformation [Intyds]. Ontrek van die wêreldwye web: http://www.polity.organisation.za/govdocs/ policy/ educ.html.

Republiek van Suid-Afrika. (1997). Education Whitepaper, programme for transformation of higher education [Intyds]. Onttrek van die wêreldwye web: http://www.polity. organisation.za/govdocs/white_papers/highed.html.

Schepers, J.M. \& Roodt, G. (2000). Werkswaardes van akademici. Johannesburg: Randse Afrikaanse Universiteit.

Schwartz, S.H. \& Bilskey, W. (1987). Toward a universal psychological structure of human values. Journal of Personality and Social Psychology, 53 (3), 550-562.

Scott, W.A. (1965). Values and organizations. Chicago: Rand McNally.

Smith, D.P.J. \& Hattingh, L. (1995). Werkwaardes en die uitlewing daarvan in ABSA. Ongepubliseerde navorsingsverslag. Johannesburg: Randse Afrikaanse Universiteit.

Smith, M.B. (1963). Personal values in the study of lives. In R.W. White (Ed.), The study of lives: Essays on personality in honor of Henry A. Murray. New York: Atherton.

Super, D.E. (1984). Perspectives on the meaning of work. In C. Norman \& Gysbers and Associates (Eds.). Designing careers. San-Fransisco: Jossey-Bass.

Swart, C., Roodt, G. \& Schepers, J.M. (1999). Itemformaat, differensiële itemskeefheid en die faktorstruktuur van 'n selfvoltooiingsvraelys. Tydskrif vir Bedryfsielkunde, 25 (1), 33-43.

Torgerson, W.S. (1958). Theory and methods of scaling. New York: John Wiley.

Venter, A (2001). Recognition of prior learning in higher education institutions [Intyds]. Onttrek van wêreldwye web http://general.rau.ac.za/hrd/ArticlesMain.htm.

Verwey, A.M. \& Fouche, M.M. (1987). Algemene lewenswaardes: 'n Loodstudie by Afrikaanssprekende universiteitstudente. Journal of Industrial Psychology, 13 (1), 6-14.

Williams, R.M., Jr. (1968). Values. in E. Sills (Ed.), International encyclopedia of the social sciences. New York: Macmillan. 